\title{
Evolution of state clusters related with technological capability in Mexico: Application of a multivariate statistical analysis of cluster
}

\author{
Evolución de la capacidad tecnológica en México. Aplicación del análisis \\ estadístico multivariante de clúster
}

Carla Carolina Pérez Hernández, Graciela Lara Gómez, Denise Gómez Hernández

Universidad Autónoma de Querétaro, Mexico

Received 16 February 2015; accepted 3 November 2015

Available online 23 March 2017

\begin{abstract}
The objective of this work is to analyze how the technological capability is distributed between the Mexican states and to examine their evolution. To this end, an empirical study was developed using the cluster multivariate statistical analysis technique, based on the set of indicators proposed by Cepal (2007), and gathering the data from various public sources in the country during years 2006 and 2012. This was done to study the evolution of said conglomerates, trying to see which states have been able to move to a conglomerate located in more advanced positions and which have retreated within said period. The results show the existence of 7 groups of states characterized by different levels of technological capability. Furthermore, 3 entities that evolved into a more advanced conglomerate - regarding absorption and innovation capability, as well as infrastructure technological capability - are also detected.

(C) 2017 Universidad Nacional Autónoma de México, Facultad de Contaduría y Administración. This is an open access article under the CC BY-NC-ND license (http://creativecommons.org/licenses/by-nc-nd/4.0/).
\end{abstract}

JEL classification: $\mathrm{O} 10 ; \mathrm{O} 30 ; \mathrm{O} 33$

Keywords: Technological capabilities; State conglomerates; Multivariate statistical analysis

E-mail address: carolina.cph@gmail.com (C.C. Pérez Hernández).

Peer review under the responsibility of Universidad Nacional Autónoma de México. 


\section{Resumen}

El objetivo del presente trabajo es analizar cómo se distribuye la capacidad tecnológica entre las entidades federativas de México y examinar su evolución. Para ello, se desarrolló un estudio empírico utilizando la técnica de análisis estadístico multivariante de clúster, con base en el set de indicadores propuesto por Cepal (2007) y recopilando los datos de diversas fuentes públicas del país para los años 2006 y 2012, con el fin de estudiar la evolución en el tiempo de dichos clústeres, tratando de ver qué estados han podido mudarse a un clúster situado en posiciones más avanzadas y cuáles han retrocedido en dicho periodo. Los resultados muestran la existencia de 7 grupos de estados caracterizados por distintos niveles de capacidad tecnológica, y se detectan también 3 entidades que evolucionaron a un clúster más avanzado, tanto en lo referente a la capacidad de absorción e innovación como en lo relativo a las capacidades tecnológicas de infraestructura. (C) 2017 Universidad Nacional Autónoma de México, Facultad de Contaduría y Administración. Este es un artículo Open Access bajo la licencia CC BY-NC-ND (http://creativecommons.org/licenses/by-nc-nd/4.0/).

Códigos JEL: O10; O30; O33

Palabras clave: Capacidades tecnológicas; Conglomerados estatales; Análisis estadístico multivariante

\section{Introduction}

Science, technology, and innovation are the main drivers of sustainable economic development (Brunner, 2011; Diaconu, 2011; Dosi, 2008; Schumpeter, 2005; Stern, Porter, \& Furman, 2000; Ulku, 2004). This justifies the realization of both national and international studies focused on measuring the technological capabilities at macro level. The studies at a state level are not as numerous. In Mexico, the Scientific and Technological Advisory Forum (FCCyT) has the task of presenting the state of Science, Technology, and Innovation (CTI) at a state and national level. However, as noted by the FCCyT (2014, p. 16), the studies developed with regard to the CTI at a state level "are incipient and require a broader, complementary, or particular analysis".

Furthermore, the concept of the National Innovation System is prone to analyzing the technological capabilities of different entities, as this helps to better understand the socioeconomic transformations of the same (Dutrénit, Capdeville, Corona, Puchet, \& Veracruz, 2010). It is indicated that competitiveness (international, national, state-wise, industrial, and corporate-wise) is built; it is an acquired advantage and, essentially, depends on the broadness and depth of the national technological capabilities (Borrastero, 2012; Calderón \& Hartmann, 2010; Close \& Garita, 2011; Guzmán, 2008; Morales, 2009). In this sense, "the technological capabilities that drive innovation have always been a fundamental component of competitiveness and the economic growth and well-being of the countries" (Velarde, Garza, \& Coronado, 2011, p. 17). Likewise, Dominguez and Brown (2004) consider pertinent to return to the initial approach regarding the importance of analyzing the level of technological capabilities, in order to better understand its differences in the situation of heterogeneity, which characterizes developing economies.

The objective of this work is to analyze how the technological capability is distributed between the Mexican states and examine its evolution. To this end, it was considered necessary to supplement and delve further into the previous proposal made by Blázquez de le Hera and García-Ochoa Mayor (2009), considering necessary to carry out an empirical study that not only explores the existence of different conglomerates of technological capability, but that also evaluates the evolution through time of said capabilities between the groups of states. This was done to detect those states that have managed to migrate into a better positioned conglomerate and those that have 
regressed in said issue, and thus create a more in-depth discussion and reflection regarding said results. The investigation was carried out using data from the years 2006 and 2012 - published in various sources (see Table 2) - which contain a series of indicators that attempt to quantify different aspects related to the technological capability.

Two periods (2006 and 2012) are analyzed with the empirical work through three stages. The first consists on reducing a great number of indicators through factorial analysis, obtaining two factors. Subsequently, these factors are analyzed to identify different groups of states using the cluster technique. Finally, an econometric test is carried out to evaluate the statistical accuracy of the conglomerates obtained. Thus, proving the existence of 7 groups of states characterized by different levels of technological capability, as well as detecting 3 entities that evolved into a more advanced conglomerate to both: absorption and innovation capability, as well as infrastructure technological capability.

\section{Brief review of concepts}

Bell, Pavitt and Lall (cited by Cepal, 2007, p. 11) indicate that the development of technological capabilities "implies knowledge and abilities to acquire, use, absorb, adapt, improve, and create new technologies" (see Fig. 1). Departing from this definition, it is understood that technological capabilities include absorption and innovation capabilities. The former is subject to aspects such as infrastructures, innovation activities, the formation of human capital, and the abilities of the countries to create, imitate, and manage knowledge, whereas the latter refers to the possibility to access, learn, and assimilate foreign technologies (Quiñones \& Tezanos, 2011).

For García, Blázquez, and Ruiz (2012), there are three types of capabilities: technological capability, absorption capability, and innovation capability (Fig. 2), which have usually been treated separately. However, the existence of elements shared between all of them has been evidenced, as well as an intense correlation that makes it possible for said capabilities to be studied in conjunction. Furthermore, given that the technological capabilities include the capabilities of absorption and innovation, the existing connection between said capabilities makes it pertinent to focus toward the technological capabilities as a central element.

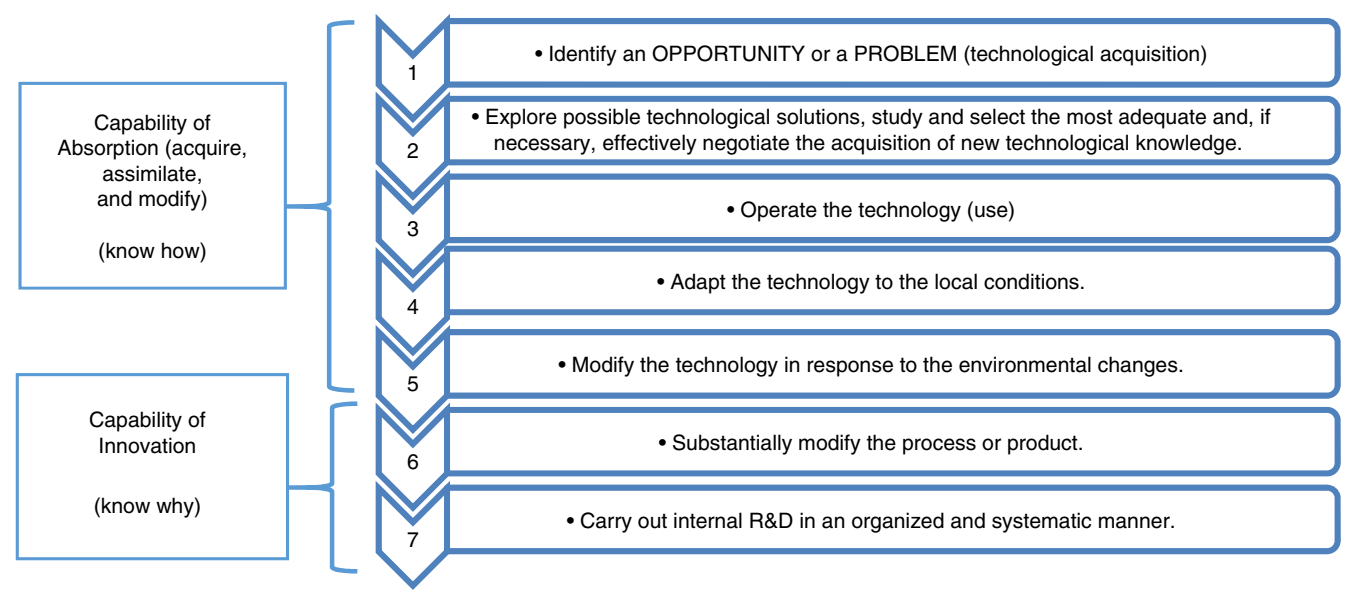

Fig. 1. Concept of the development of technological capabilities.

Source: Own elaboration based on Cepal (2007), Quiñones and Tezanos (2011), and Ortega (2005). 


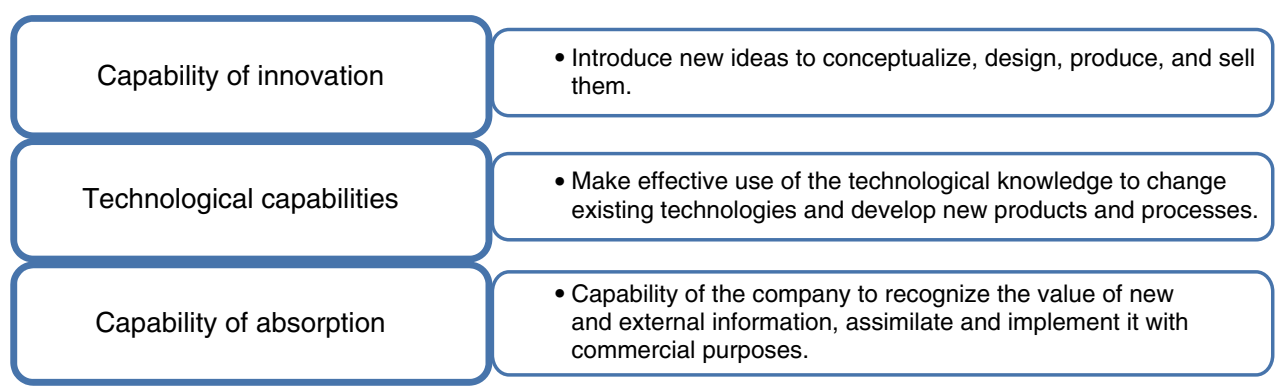

Fig. 2. Types of capabilities.

Source: Own elaboration based on Biggs, Shah, and Srivastava (1995) and García et al. (2012).

Cepal (2007) considers possible to identify the accumulation of technological capabilities at the microeconomic level (in the signatures), but also at the national (macroeconomic) and sectorial (mesoeconomic) level. Furthermore, it establishes that the analysis of the technological capabilities allows the consideration of three dimensions: (1) the available base (human resources, infrastructure, 'quality' of the environment); (2) the efforts made for the increase and consolidation of the capabilities (the acquisition of knowledge in its different forms, $R \& D$, among others); (3) the results achieved derived from the existing capabilities (patents, rate of innovation, and technological content of the exports).

On the other hand, by speaking of the technological capabilities of a nation or region, it is necessary to identify them as inherent to the National Innovation System, given that this, according to Dutréit and Sutz (2014), centers on the actors, the institutions, and their relations, which contribute to a better understanding of both the intrinsic dynamic of innovation as well as its connections with the development processes. Consequently, according to Buesa, Martínez, Heijs, and Baumert (2002), the Regional Innovation System concept alludes to a group of institutional and corporate organizations that, within a determined geographical scope, interact with each other to allocate resources for the realization of activities directed to the generation and dissemination of knowledge which support the innovations (mainly technological) that are the bases for economic development.

In this sense, Rózga (2003) notes that the future depends on how the Regional Innovation Systems respond to the territorial challenges of creating the synergies that shall correspond to the needs of generating technological knowledge, which shall help produce territorial innovation networks. One way to recognize said networks is by studying the territorial reality and identifying their technological capability by regions or groups.

\section{National empirical studies}

In Mexico, there are studies at a national level that are highly reduced, above all, stratified to a state by state level, due in great measure to the fact that the availability of the data by state is limited. To date, there are 5 studies (see Table 1) that delineate the relative geography to the technological and/or innovation capability from various methodologies.

It is worth noting that this work follows the methodology proposed by Pérez and Lara (2015), however, under this research not only are the conglomerates of technology capability identified, but their evolution through time is also evaluated and solid arguments are assigned that deepen 
Table 1

National empirical studies.

\begin{tabular}{|c|c|c|c|}
\hline Indicator/author & Statistical technique & Indicators & Contributions \\
\hline $\begin{array}{l}\text { Index of Knowledge } \\
\text { Economy/Fundación Este } \\
\text { País (2005 and 2007) }\end{array}$ & $\begin{array}{l}\text { Statistical standardization on } \\
\text { maximum and minimum } \\
\text { values, based on UNDP } \\
\text { methodology. }\end{array}$ & 15 & $\begin{array}{l}\text { The objective was to analyze the } \\
\text { extent to which the states of the } \\
\text { Republic and the country as a whole } \\
\text { had the necessary attributes to move } \\
\text { toward a knowledge-based economy } \\
\text { and to compete favorably. }\end{array}$ \\
\hline $\begin{array}{l}\text { Index of Innovation Potential } \\
\text { at State Level/Ruiz D.C. } \\
\text { (2008) }\end{array}$ & $\begin{array}{l}\text { Stockings trimmed, } \\
\text { normalizing the values of the } \\
\text { variables by the difference } \\
\text { between the maximum value } \\
\text { and the minimum value. }\end{array}$ & 7 & $\begin{array}{l}\text { He proposed a monitoring of the } \\
\text { innovation potential of the federative } \\
\text { entities. For its part, this indicator } \\
\text { established a classification of states } \\
\text { according to their level of innovation } \\
\text { in three categories. }\end{array}$ \\
\hline $\begin{array}{l}\text { Index of State } \\
\text { Innovation/Aregional } \\
(2010)\end{array}$ & $\begin{array}{l}\text { Standardization methodology } \\
\text { of the European Regional } \\
\text { Innovation Scoreboard, } 2009 \\
\text { and Main Components. }\end{array}$ & 37 & $\begin{array}{l}\text { It classified the federative entities } \\
\text { according to their level of innovation, } \\
\text { based on the following } \\
\text { classifications: medium-high } \\
\text { innovation; Average innovation; } \\
\text { Medium-low innovation; Low } \\
\text { innovation and low innovation. }\end{array}$ \\
\hline $\begin{array}{l}\text { National Ranking of Science, } \\
\text { Technology and } \\
\text { Innovation/FCCyT (2011) }\end{array}$ & $\begin{array}{l}\text { Statistical normalization on } \\
\text { the average value and } \\
\text { weighting agreed by the main } \\
\text { actors and scholars of the STI } \\
\text { Public Policy in Mexico. }\end{array}$ & 43 & $\begin{array}{l}\text { He planned to have a comparative } \\
\text { measure of the quantity and quality } \\
\text { of resources in ITC with which each } \\
\text { federal entity counted, and position } \\
\text { them in a progressive order to } \\
\text { identify strengths and areas of } \\
\text { opportunity. }\end{array}$ \\
\hline $\begin{array}{l}\text { State clusters of technological } \\
\text { capacity and } \\
\text { innovation/Pérez, Gómez, } \\
\text { and Lara (2015) }\end{array}$ & $\begin{array}{l}\text { Statistical normalization on } \\
\text { maximum and minimum } \\
\text { values, factorization and } \\
\text { cluster multivariate analysis. }\end{array}$ & 16 & $\begin{array}{l}\text { The results show the existence of } 7 \\
\text { groups of states characterized by } \\
\text { different levels of technological } \\
\text { capacity, } 3 \text { entities were also detected } \\
\text { that evolved to a more advanced } \\
\text { cluster, both in terms of the capacity } \\
\text { of absorption and innovation, as well } \\
\text { as in relation to the capacities } \\
\text { Technological infrastructure. He used } \\
\text { the taxonomy proposed by Cepal } \\
\text { (2007). }\end{array}$ \\
\hline
\end{tabular}

Source: Own elaboration based on FCCyT (2014).

the reflection regarding technological capabilities throughout the national territory; highlighting the importance of promoting the latter without creating greater regional unbalances.

It can be deduced that the different methodologies for the measurement of the technological and innovation activity that is carried out in the country, whether they are different-complementary methodologies and of little comparison, point in the same direction: there are clear unbalances in the subject matter. Furthermore, it is considered that the persisting breaches, specifically those of technological capability, are better illustrated by carrying out a cluster analysis as shown in this investigation, thus proving the advancement of some of the entities with the passage of time. 


\section{Review of the indicators utilized}

Chinaprayoon (2007) notes that one of the peculiarities of technology is its variety and, therefore, the technological capabilities that are comprised of heterogeneous elements, including research activities, infrastructure, stock of knowledge, human resources, among others. Because of this, it is impossible to use a single indicator to explain the technological capabilities of a nation or state.

In this article, a series of indicators was used that directly and indirectly measure different relevant aspects of the technological capability for the 32 Mexican states. Given that the advantage of using a set of indicators is well known, it is thus possible to define the situation of each country with greater accuracy (in this case the state-wise situation), providing an easier understanding of the differences between them.

For this study focused on the national-sectorial technological capability, we consider pertinent to adopt the taxonomy of the Cepal (2007), given that this agglomerates dimensions and indicators, while taking into account the innovation system for Developing Countries. Other taxonomies ${ }^{1}$ focus their studies on developed countries, where the behavior and technological indicators differ. Furthermore, said indicators are found disaggregated at the state level and thus we are able to recognize the dynamics of the technological capability at the mesoeconomic level.

In this sense, some variables were adapted in relation to the dimension of 'the efforts carried out' and 'the results achieved' given that as Archibugi and Coco (2005) note, in many cases the variables are dictated by the availability of the statistical sources, more so than by the theoretical preferences. For this study, the years 2006 and 2012 were chosen as there is public information available.

It is important to note that the data utilized for this work were derived from two sources: published data regarding the years 2006 and 2012 (hard data) and data from the Survey on Technological Research and Development and the Module on Activities of Biotechnology and Nanotechnology (survey data). ${ }^{2}$

To make the data comparable, these were normalized in accordance with the formula to compare individual indicators proposed by Archibugi and Coco (2004), which is expressed as follows: (observed value - minimum value)/(maximum value - minimum value); range of the indices: [0 and 1].

\section{Methodology and result analysis}

The methodology of this work consists on developing a cluster multivariate statistical analysis for the years 2006 and 2012 that, as its first point, shows the results regarding the descriptive statistics of the previously normalized variables. Subsequently, the factorial analysis is carried out to highlight the main components relative to the study of technological capability. Third, an analysis of hierarchical conglomerates is done, better known as a cluster analysis, to identify the

\footnotetext{
${ }^{1}$ Other taxonomies of technological capability are focused on developed entities (Archibugi and Coco, 2004; Lall, 1992). Furthermore, Torres (2006) notes that the starting point of the analysis is that the Developing Countries are borrowers or learners, that is to say, that they borrow and learn technology developed by the developed countries and thus ought to have different indicators.

2 The survey is known as "soft data" and generally is obtained from samples of the surveys (not of entire populations). For the INEGI, the ESIDET-MBN 2012 is the first special survey in companies with state geographical coverage and, therefore, the set for the year 2006 does not employ said variable.
} 
Table 2

Indicators used in the empirical analysis by entities for the years 2006 and 2012.

Available base

The available base reflects human resources and infrastructure, which reveal the "quality of the environment

\begin{tabular}{|c|c|}
\hline Variables & Definitions \\
\hline Telephone lines & $\begin{array}{l}\text { Density of fixed-line telephones in service per state. Lines } \\
\text { for every } 100 \text { inhabitants. }\end{array}$ \\
\hline Internet users & $\begin{array}{l}\text { Internet and computer users per state. Users for every } 100 \\
\text { inhabitants. }\end{array}$ \\
\hline Literacy rate & $\begin{array}{l}\text { Percentage of the population that is older than } 15 \text { years of } \\
\text { age that knows how to read and write per state. Literate } \\
\text { population for every } 100 \text { inhabitants older than } 15 \text { years of } \\
\text { age. }\end{array}$ \\
\hline $\begin{array}{r}\text { Electric energy } \\
\text { consumption }\end{array}$ & $\begin{array}{l}\text { Total electric energy consumption per capita per state. } \\
\text { Gigawatts per hour, per capita. }\end{array}$ \\
\hline $\begin{array}{l}\text { Researchers dedicated to } \\
\text { research and } \\
\text { development }\end{array}$ & $\begin{array}{l}\text { Researchers belonging to the SNI, dedicated to research and } \\
\text { development per million inhabitants per state. }\end{array}$ \\
\hline $\begin{array}{l}\text { Graduates in Engineering } \\
\text { and Technology }\end{array}$ & $\begin{array}{l}\text { Number of graduates in Engineering and Technology per } \\
\text { state. }\end{array}$ \\
\hline Tertiary recruitment & $\begin{array}{l}\text { Enrollment of higher education students, spanning from } \\
\text { Bachelor to any Post-graduate degree. Number of students } \\
\text { per state. }\end{array}$ \\
\hline Secondary recruitment & $\begin{array}{l}\text { Enrollment of higher secondary education students, } \\
\text { spanning technical professional and high school. Number of } \\
\text { students per state. }\end{array}$ \\
\hline Primary recruitment & $\begin{array}{l}\text { Enrollment of basic education students, spanning preschool, } \\
\text { primary and secondary school. Number of students per state. }\end{array}$ \\
\hline GDP & $\begin{array}{l}\text { Set of goods and services produced in a state during the } \\
\text { course of a year. Millions of MXN\$ at the constant prices of } \\
2008 \text {. }\end{array}$ \\
\hline GDP per capita & $\begin{array}{l}\text { Gross Domestic Product per capita per state. MXN\$ at the } \\
\text { constant prices of } 2008 \text {. }\end{array}$ \\
\hline
\end{tabular}

Source/year

(CMIC, 2006, 2012)

(INEGI, 2012)

(INEGI, 2006, 2012)

(CFE, 2006, 2012)

(CONACYT, 2006, 2012)

(ANUIES, 2006, 2012)

(SEP, 2006, 2012)

(SEP, 2006, 2012)

(SEP, 2006, 2012)

(INEGI, 2006, 2012)

(INEGI, 2006, 2012)

The efforts carried out

This dimension reflects the efforts carried out for the increase and consolidation of the capabilities (Acquisition of knowledge in its different forms, $\mathrm{R}+\mathrm{D}$, among others)

\begin{tabular}{lll}
\hline Variables & Definitions & Source/year \\
\hline Company R\&D expenses & $\begin{array}{l}\text { Expenses allocated by companies of the productive sector } \\
\text { on Technological research and development activities } \\
\text { within its borders per state. Thousands of MXN\$. } \\
\text { Foreign direct investment per state. Millions of USD\$. }\end{array}$ & (INEGI, 2012) \\
FDI & (SE, 2006, 2012)
\end{tabular}

The results achieved

This dimension shows the results achieved from the existing capabilities (patents, rate of innovation, and technological content of exports)

\begin{tabular}{lll}
\hline Variables & Definitions & Source/year \\
\hline $\begin{array}{l}\text { Articles in scientific } \\
\text { publications }\end{array}$ & $\begin{array}{l}\text { Articles published by Mexican principals in scientific and } \\
\text { technical publications per state. }\end{array}$ & (CONACYT, 2012) \\
Requested patents & $\begin{array}{l}\text { Patents requested in Mexico by Mexican principals per state } \\
\text { for every 100 thousand inhabitants. }\end{array}$ & (IMPI, 2006, 2009) \\
Patents granted & $\begin{array}{l}\text { Patents requested in Mexico by Mexican principals per state } \\
\text { for every 100 thousand inhabitants. }\end{array}$ & (IMPI, 2006, 2009) \\
& & \\
\hline
\end{tabular}

Source: Own elaboration based on the taxonomy of Cepal (2007). 
Table 3

Descriptive statistics (year 2006 and 2012).

\begin{tabular}{|c|c|c|c|c|c|c|}
\hline Variables & $\begin{array}{l}\text { Mean } \\
2006\end{array}$ & $\begin{array}{l}\text { Mean } \\
2012\end{array}$ & Variation $\%$ & $\begin{array}{l}\text { Standard } \\
\text { deviation } \\
2006\end{array}$ & $\begin{array}{l}\text { Standard } \\
\text { deviation } \\
2012\end{array}$ & Variation $\%$ \\
\hline Foreign direct investment & 0.066 & 0.088 & $33 \%$ & 0.175 & 0.175 & $0 \%$ \\
\hline Patents granted & 0.067 & 0.124 & $85 \%$ & 0.178 & 0.240 & $35 \%$ \\
\hline Researches & 0.068 & 0.169 & $149 \%$ & 0.173 & 0.199 & $15 \%$ \\
\hline GDP per capita & 0.088 & 0.114 & $30 \%$ & 0.172 & 0.174 & $1 \%$ \\
\hline Patents requested & 0.098 & 0.167 & $70 \%$ & 0.198 & 0.222 & $12 \%$ \\
\hline GDP MX \$ million & 0.152 & 0.155 & $2 \%$ & 0.196 & 0.196 & $0 \%$ \\
\hline Gross Tertiary Enrollment & 0.162 & 0.171 & $6 \%$ & 0.2 & 0.209 & $5 \%$ \\
\hline Gross Primary Enrollment & 0.211 & 0.206 & $-2 \%$ & 0.206 & 0.203 & $-1 \%$ \\
\hline Gross Secondary Enrollment & 0.228 & 0.218 & $-4 \%$ & 0.237 & 0.222 & $-6 \%$ \\
\hline Telephone line & 0.322 & 0.248 & $-23 \%$ & 0.192 & 0.184 & $-4 \%$ \\
\hline Energy consumption & 0.419 & 0.419 & $0 \%$ & 0.256 & 0.256 & $0 \%$ \\
\hline Alphabetization rate & 0.697 & 0.703 & $1 \%$ & 0.267 & 0.268 & $0 \%$ \\
\hline Scientific publications & N.A & 0.062 & N.A & N.A & 0.174 & N.A \\
\hline Internet users & N.A & 0.484 & N.A & N.A & 0.282 & N.A \\
\hline R\&D expenditure (companies) & N.A & 0.06 & N.A & N.A & 0.178 & N.A \\
\hline Titles (Engineering \&Technology) & N.A & 0.173 & N.A & N.A & 0.199 & N.A \\
\hline
\end{tabular}

$N$ valid 32 (according to list). N.A = data not available in that year.

Source: Own elaboration (SPSS 21).

groups of states that share similar characteristics. Finally, an econometric test is performed for the validation of the cluster analysis. The methods mentioned shall be described in detail in the following sections.

\section{Review of the descriptive statistics}

In this section, the previously normalized descriptive statistics are presented for the analyzed years, in which it is considered that, by taking the smaller datum and applying to it the normalization formula, a result of zero is obtained. Likewise, the greater datum shall be one. Therefore, these data define the range $[0,1]$ and all the other data shall be contained in said interval. It could be understood that the datum becomes a percentage, in which $0 \%$ is the minimum value and $100 \%$ is the maximum value, and the variables in question represent some percentage between 0 and 100 .

The descriptive statistics that result to be useful in the analysis are the median and the standard deviation (as is shown in Table 3). For most of the variables, the median has a small growth and the standard deviation is maintained equal or almost equal, which implies that most of the states grew approximately by the same quantity.

However, variables such as foreign direct investment or the GDP per capita show a significant growth in the median. Nevertheless, the standard deviation remains very similar. This would indicate that most of the states significantly increased their value in these variables, but maintained the same dispersal in their differences with regard to the rest of the states. It could be interpreted that there was a certain factor that affected all the states, causing the generalized increased in the values.

On the other hand, variables such as patents granted, the number of researchers, and the GDP increased their medians in great measure, and suffered significant changes in their standard 
Table 4

KMO and Bartlett test for years 2006 and 2012.

\begin{tabular}{lrr}
\hline KMO and Bartlett test & Year 2006 & Year 2012 \\
\hline Measurement of Kaiser-Meyer-Olkin sample adequacy. & .763 & .717 \\
$\quad$ Approximate Chi-square & 662.559 & 865.127 \\
Bartlett sphericity test & 66 & 120 \\
$\quad$ df & .000 & .000 \\
Sig. &. &. \\
\hline
\end{tabular}

Source: Own elaboration (SPSS 21).

deviations, as well. This means that the states grew, but some more than others. It could be interpreted that there was no single factor that caused the changes in all the states for these variables, but rather that each state changed due to its own causes. Finally, it ought to be emphasized that the telephone lines variable suffered a decrease in its median; said variable, according to Chinaprayoon (2007), is considered a diffuser of old technologies, in contrast with the internet and the mobile phone lines that represent the diffusion of new technologies.

\section{Factor analysis}

The purpose of the factor analysis is to identify the explicative variables that best examine the distribution of the technological capability between states. Therefore, the objective of the factor analysis is to extract a lesser number of factors that explain most of the sample variance; this is a broadly utilized and accepted technique in this type of studies (Archibugi, 1988). However, prior to the factor analysis, a study was carried out on the viability of performing it for the set of data, (year 2006 and 2012), for which the Kaiser-Meyer-Olkin tests (KMO) and the Bartlett sphericity tests (Table 4) were utilized.

The KMO index is used to compare the magnitudes of the multiple correlation coefficients observed with the magnitudes of partial correlation coefficients (Álvarez, 1995). When the index value is low, less than 0.5 , the application of the analysis is not advised, given that the correlations between pairs of variables cannot be explained through the other variables. The closer the KMO index is to 1 , the more adequate the use of the factor analysis results. It is observed that for the year 2006, the KMO index is $=.763>.5$, therefore, it makes sense to carry out a factor analysis. The same happens for the year 2012, given that the KMO index $=.717>0.5$.

On the other hand, the Bartlett sphericity test verifies if there are interrelations between the variables through the enunciation of the null hypothesis, which indicates that the correlation matrix is the identity matrix (the one that has ones in the main diagonal and zeros in the rest of the values). If the null hypothesis is confirmed, it would be assumed that the variables are not correlated. On the contrary, if the null hypothesis is rejected, the variables would be related and it would be adequate to carry out the factor analysis (Pedroza, 2006).

For both periods, 2006 and 2012, the $p$ value associated with the Bartlett sphericity test is less than .05 , thus the $\mathrm{H}_{0}$ is rejected and, therefore, it makes sense to carry out a factor analysis. Table 5 brings together the results of the factors for the years 2006 and 2012, respectively. Jointly, these two factors explain a high percentage of the sample variance (between $74.26 \%$ and $78.65 \%$, respectively), which is significant at conventional levels and thus indicates that these factors represent most of the variability in the data. 
Table 5

Results of the rotated Components Matrix.

\begin{tabular}{lc}
\hline $\begin{array}{l}\text { Factor } 1 \\
\text { Capacity to absorb and innovate }\end{array}$ & Factor 2 \\
Axis of the graph Y & Axis of the graph X \\
Gross Tertiary Enrollment & Internet users \\
Titles (Engineering \& Technology) & Alphabetization rate \\
GDP constant prices & Energy consumption \\
R\&D expenditure (companies) & GDP per capita \\
Foreign direct investment & Telephone lines \\
Scientific publications & \\
Gross secondary winding & \\
Gross Primary Enrollment & \\
Patents requested & \\
Researchers & \\
Patents granted &
\end{tabular}

Note: Variables with saturations greater than .5 are chosen for each factor.

Source: Own elaboration based on results Rotated Components Matrix (SPSS 21).

FACTOR 1: This is a combination of 11 variables that entails $58.5 \%$ of the sample variance in the year 2006 and $54.7 \%$ in the year 2012, thus implying to be a rather relevant dimension to analyze the differences in the technological capability between states. Factor 1, according to the literature, could be interpreted as the capability of absorption and innovation. FACTOR 2: This is a combination of 5 variables that entails $19.5 \%$ of the sample variance in the year 2012 and $20.1 \%$ in the year 2006. Factor 2, according to the literature, could be interpreted as infrastructure technological capability.

Table 5, denominated Rotated Components Matrix, presents the existing correlation (saturation) between each of the variables and their corresponding factor. The saturation represents the weight (the significance) of the variable within the factor. It is worth mentioning that unlike what occurs with other techniques such as the variance or regression analyses, in the factor analysis all the variables of the analysis fulfill the same role: all of them are independent in the sense, in principle, that there is no conceptual dependency of some variables over others. Therefore, the variables of both factors $(X$ and $Y$ ) are considered independent.

The meaning of the obtained factors ought to be clarified. Factor 1 (graphed in the axis of the $Y$ ), denominated the absorption and innovation capability, includes variables relative to the rate of enrollment, human resources dedicated to research, science and technology; said variables entail the capability of the states to recognize the value of new and external information, to assimilate and implement it with commercial purposes. Moreover, within this same factor are the variables of results achieved such as the patents that were requested and granted, the expenditure on research and development of the companies per state, and the indicators that show the capability of the states to introduce new ideas, conceptualize, design, produce and sell them. Another one of the variables included in factor 1 is the one regarding Foreign Direct Investment, which exemplifies the acquisition of external knowledge of the states.

On the other hand, factor 2, labeled infrastructure technological capability, considers as indicators the electric energy consumption, telephone lines and internet users, ${ }^{3}$ variables considered

\footnotetext{
${ }^{3}$ For Chinaprayoon (2007), internet users are an indicator of the diffusion of new technologies, whereas electric energy consumption and telephone lines are indicators of the diffusion of old technologies.
} 
as pertaining to infrastructure that provide a general understanding of the environment in which the productive activities of the Mexican republic develop; the combination of these three aspects offers signs of the degree of sophistication of the production, "as it could be assumed that a greater value of the indicators in question corresponds to a greater sophistication, which ought to be translated into a greater aggregated value in the production" (Cepal, 2007, p. 32). Furthermore, said factor adds the literacy rate as a metric of the general level of the productive environment. Finally, the GDP per capita indicator is included, as it is known that the products with greater technological content (or knowledge content) are characterized by a greater elasticity of the demand. In others, the GDP per capita is an indicator of the complexity of the technological demand. ${ }^{4}$

\section{Cluster analysis}

Cluster analysis is the name given to a set of multivariate techniques whose main purpose is to group together objects based on their characteristics. The resulting conglomerates ought to show a high degree of internal homogeneity within the conglomerate and a high degree of external heterogeneity of the same (Álvarez, 1995). In this case, the partition of a set of data (corresponding to different states) was sought in the groups, so that the data belonging to a single group are very similar among each other, but very different from the other groups. In order to manage to form homogeneous groups of observations (of states in this case), their similarity or distance (dissimilarity) must be measured. In this regard, numerous methods have been developed to measure the distance between the cases. In this work, the Euclidean distance was utilized, which measures the similarity between analysis units that have been evaluated in a set of metric variables (quantitative).

\section{The state conglomerates and their evolution in the 2006-2012 period}

The analysis of hierarchical conglomerates (cluster analysis) begins with the calculation of the distance matrix among the sample elements. This matrix contains the existing distances between each element and all the remains of the samples. Subsequently, the two closest elements are found (i.e., the two more similar in terms of distance) and are grouped in a conglomerate. The resulting conglomerate is indivisible from that moment onward (thus the hierarchical name assigned to the procedure). In this manner, the elements are grouped into conglomerates each time larger and more heterogeneous among themselves, until reaching the final step in which all the sample elements are grouped into a single, global conglomerate. The hierarchical conglomerates procedure of the SPSS informs of all the steps carried out in the analysis, thus it is easy to appreciate what elements or conglomerates are cast in each step and at what distance they were when they fused. This allows the evaluation of the heterogeneity of the conglomerates. This section presents the results of the cluster multivariate statistical analysis, which divides the Mexican states into 7 groups or conglomerates characterized by different levels of technological capability in the periods of 2006 and 2012. Table 6 shows the states that are part of each of the groups in the two periods considered.

Regarding technological capabilities, Mexico moves at 7 different steps. The state conglomerates of technological capability obtained are described below:

\footnotetext{
${ }^{4}$ It is expected that the growth of the economic activity and income derive from an increase on the demand of more complex or technologically advanced goods (Cepal, 2007).
} 
Table 6

Clusters obtained.

\begin{tabular}{|c|c|c|c|c|c|}
\hline Cluster & 2006 & 2012 & Cluster & 2006 & 2012 \\
\hline 1 & D.F & D.F & \multirow{13}{*}{6} & Campeche & Durango \\
\hline 2 & Nuevo León & $\begin{array}{l}\text { Nuevo León } \\
\text { Querétaro* }\end{array}$ & & $\begin{array}{l}\text { Durango } \\
\text { Guanajuato }\end{array}$ & $\begin{array}{l}\text { Guanajuato } \\
\text { Hidalgo }\end{array}$ \\
\hline 3 & Jalisco & Jalisco & & Hidalgo & Michoacán \\
\hline \multirow[t]{6}{*}{4} & México & México & & Michoacán & Nayarit \\
\hline & Aguascalientes & Aguascalientes & & Morelos* & SLP \\
\hline & $\mathrm{BCN}$ & $\mathrm{BCN}$ & & Nayarit & Sinaloa \\
\hline & BCS & BCS & & Querétaro* & Tabasco \\
\hline & Coahuila & Campeche & & SLP & Tlaxcala \\
\hline & Colima & Coahuila & & Sinaloa & Yucatán \\
\hline \multirow[t]{9}{*}{5} & Chihuahua & Colima & & Tabasco & Zacateca \\
\hline & Quintana Roo & Chihuahua & & Tlaxcala & \\
\hline & Sonora & Morelos & & Yucatán & \\
\hline & Tamaulipas & Quintana Roo & & Zacatecas & \\
\hline & & Sonora & & Veracruz & Veracruz \\
\hline & & Tamaulipas & & Puebla & Puebla \\
\hline & & & 7 & Guerrero & Guerrero \\
\hline & & & & Oaxaca & Oaxaca \\
\hline & & & & Chiapas & Chiapas \\
\hline
\end{tabular}

Source: Own elaboration based on the conglomerate results (SPSS 21).

* The states marked with an asterisk (Querétaro, Morelos, Campeche) are those that managed to migrate to a more advanced cluster.

Conglomerate 1: Excellent in absorption and innovation capability and good in infrastructure technological capability. In this conglomerate, only Mexico City can be found for both periods of time, by having a clearly outstanding position with regard to these two components. However, there has been no visible evolution in either of the two factors in the periods considered. On the contrary, it seems to have slightly decreased in the factors analyzed from 2006 to 2012.

Conglomerate 2: Regular in absorption and innovation capability and excellent in infrastructure technological capability. This group is found at a considerable distance regarding conglomerate 1, comprised of Mexico City, in terms of absorption and innovation capability. However, this group has a better position in terms of infrastructure technological capability. In 2006, this conglomerate was comprised solely by Nuevo León, however, in 2012 it is comprised by Nuevo León and Querétaro, with the latter having come from group 6, in 2006, fundamentally due to its improvement on both factors.

Conglomerate 3: Good in absorption and innovation capability with low deficit in infrastructure technological capability. Jalisco is found in this conglomerate, both in 2006 and 2012. On the one hand, it is well positioned within the absorption and innovation capability component, but it has a slightly negative positioning regarding the infrastructure technological capabilities.

Conglomerate 4: Good in absorption and innovation capability with average deficit in infrastructure technological capability. The State of Mexico can be found in this conglomerate. It can be observed that they present a positive position in the first component (only below that of conglomerate 1), though they are found in the negative quadrant for the second component. 
Conglomerate 5: Low deficit in absorption and innovation capability and regular in infrastructure technological capability. This group was comprised by nine states in 2006 (Aguascalientes, Baja California Norte, Baja California Sur, Coahuila, Colima, Chihuahua, Quintana Roo, Sonora, Tamaulipas). In 2012, all those states remained in this group, with no observable evolution. However, for this year the states of Campeche and Morelos were added to this group (having previously been in conglomerate 6 in 2006), the progress of which was mainly due to the improvement in both factors.

Conglomerate 6: Average deficit in absorption and innovation capability and average deficit in its infrastructure technological capability. This group was comprised by 14 states in 2006 (Campeche*, Durango, Guanajuato, Hidalgo, Michoacán, Morelos*, Nayarit, Querétaro*, SLP, Sinaloa, Tabasco, Tlaxcala, Yucatán, and Zacatecas). In 2012, all those states remained in this group, except for Campeche*, Morelos* and Querétaro*, which migrated to groups in more advanced positions. Campeche and Morelos advanced to conglomerate 5, whereas the state of Querétaro moved from conglomerate 6 to 2 due to a slight improvement in factor 1 and a vast improvement with regard to factor 2.

Conglomerate 7: Low deficit in absorption and innovation capability and elevated deficit in infrastructure technological capability. This group was comprised by 5 states in 2006 (Veracruz, Puebla, Guerrero, Oaxaca, Chiapas). In 2012, all those states remained in this group. Furthermore, the states of Veracruz and Puebla could be observed at the limit of the group, with tendencies of migrating to a more advanced group.

These groups can be more clearly observed in Figure 3, which shows all the states ordered according to the two factors obtained.
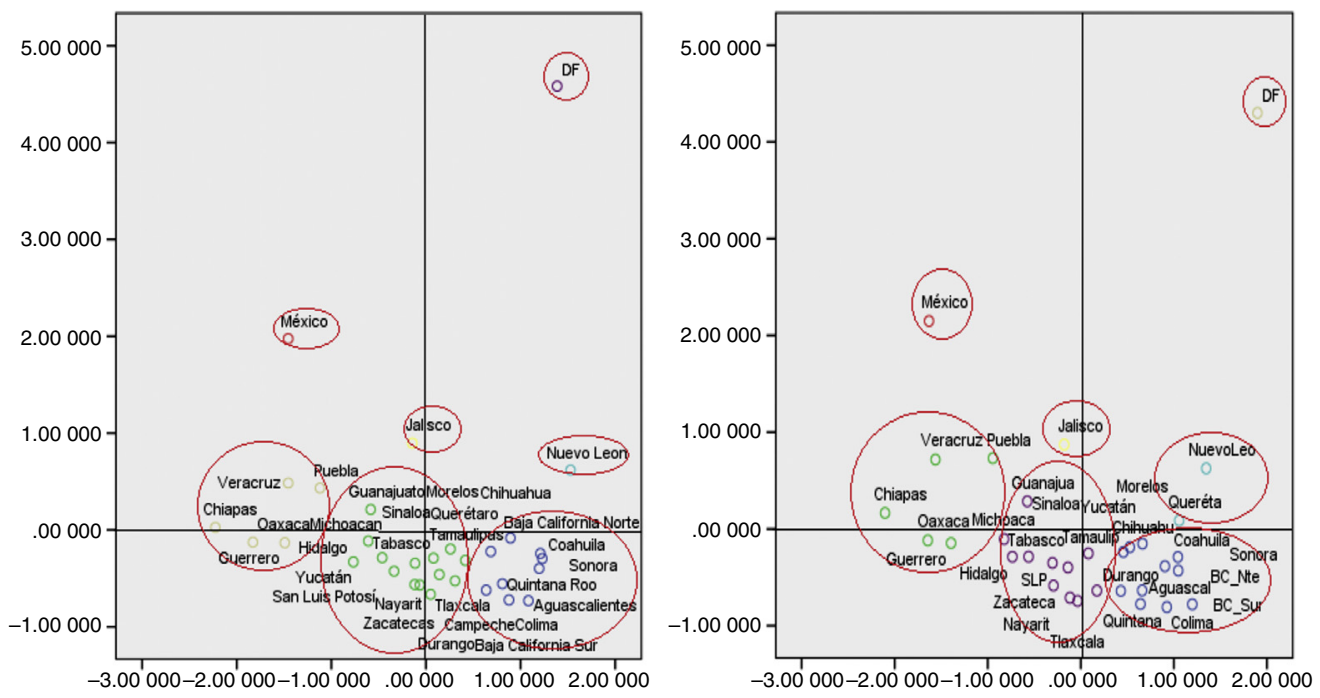

Average linkage (Between groups)

$\begin{array}{lllllll}01 & \circ 2 & \circ & \circ 4 & 5 & \circ 6 & \circ 7\end{array}$

Fig. 3. Dispersion graphics for 2006 and 2012. $X$ axis: infrastructure technological capacity. $Y$ axis: capacity to absorb and innovate.

Source: Own elaboration (SPSS 21). 


\section{Triangulation of the results obtained with other indicators}

At the end of the XVIII century, the geography hypothesis was a broadly accepted theory for the causes of global inequality, which affirms that the large gap between rich and poor entities is due to geographical differences. Presently, this argument of economic development has been overcome, as in fact, there is no simple or long-lasting cohesion between the climate or geography and economic success-geography does not mark the destiny of any country-(Acemoglu \& Robinson, 2013). However, in the XXI century, mapping the geography of innovation (and in this case, of the underlying technological capability) takes relevance as to evidence the bias of the technology policy that concentrates its efforts in a few entities or that incentivizes (in an inadequate manner) the generation of technological and innovation capabilities, thus generating greater regional-state imbalances. With the aforementioned, we show the importance of the relationship between technological capability and economic development. In this sense, the obsession to measure the technological capability lies in that, theoretically, increasing it would lead to increase the levels of innovation, which in turn is expected to impact the economic, social, and environmental sphere of a region. Therefore, it is pertinent to triangulate the results obtained relative to the state conglomerates of technological capability with other indicators, such as: The Human Development Index (HDI), ${ }^{5}$ Multidimensional Poverty, ${ }^{6}$ and the State Competitiveness Index (SCI). ${ }^{7}$ These indicators demonstrate not only the standard of living but also the quality of life of the inhabitants of the different entities.

It is coincidental that the conglomerates with greater technological capability show favorable or acceptable results in terms of competitiveness, quality of life, and reduction of poverty, whereas the conglomerates with a greater deficiency in technological capability manifest clear socioeconomic issues. Even though this study does not prove the causality of both variables (technological capability and economic development), it reflects their relationship with each other favorably.

It is worth emphasizing the following conjectures to contextualize the triangulation carried out: conglomerate 7 (the weakest in technological capability) shows the lowest levels within the HDI, which implies categorical inefficiencies in the access to health services, education and a decent standard of living. Furthermore, it presents the highest average multidimensional poverty level $(66.14 \%)$, meaning that more than half of the population of Veracruz, Puebla, Guerrero, Chiapas, and Oaxaca endure not only a weakened technological capability, but also social deficiencies (of education, health, social security, housing, basic services, and nutrition), and an income lower than the well-being line, ${ }^{8}$ as well. Finally, this conglomerate experiences the lowest state competitiveness (below the national average). Conglomerates 6 to 1 show a gradual worst to best behavior in the contrasted rubrics (see Table 7).

Regarding the entities that showed advances in terms of technological capability during the evaluated period (Querétaro, Campeche, and Morelos), Querétaro stands out given that in the

\footnotetext{
${ }^{5}$ Synthesizes the advance obtained in three basic dimensions for the development of the people: the possibility of enjoying a long and healthy life, education, and access to resources to enjoy a dignified life (PNUD, 2015).

${ }^{6}$ Percentage of the population in multidimensional poverty, i.e., that has an income below the Well-being Line and that suffers at least one social deficiency (CONEVAL, 2015).

7 Measures the capability of the states to attract and keep talent and investments. To measure this, the structural and circumstantial capabilities of the entities are evaluated (IMCO, 2014).

8 The Well-Being line is the monetary value of a food basket and a non-food basket for basic consumption.
} 
Table 7

Triangulation of the conglomerates with other indicators.

Technological capability HDI Multidimensional poverty $\quad$ State competitiveness
conglomerates

\section{Conglomerate 7}

Veracruz, Puebla,

Guerrero, Oaxaca,

Chiapas.

\section{Conglomerate 6}

Durango, Guanajuato,

Hidalgo, Michoacán,

Nayarit, SLP, Sinaloa,

Tabasco, Tlaxcala,

Yucatán and Zacatecas.

\section{Conglomerate 5 \\ Aguascalientes, Baja \\ California Norte, Baja \\ California Sur, Coahuila, \\ Colima, Chihuahua, \\ Quintana Roo, Sonora, \\ Tamaulipas \\ Campeche and Morelos}

\section{Conglomerate 4}

State of Mexico

\section{Conglomerate 3 \\ Jalisco}

\section{Conglomerate 2}

Nuevo León and

Querétaro

\section{Conglomerate 1 \\ Mexico City}

$\begin{array}{ll}\text { Low HDI level: } & \text { Average poverty } \\ (0.667-0.720) & \text { level }=66.14 \%\end{array}$

Oaxaca, Chiapas, and

Veracruz increased their

poverty level on average by

$3.9 \%$ from 2012 to 2014 .

Puebla maintained its

poverty level of $64.5 \%$.

Guerrero decreased from

$69.7 \%$ to $65.2 \%$

Are entities with a medium to low HDI level: (0.667-0.742)

Average poverty

level $=49.02 \%$

Where: Guanajuato,

Hidalgo, Michoacán,

Sinaloa, and Tlaxcala increased their poverty level on average by $2.5 \%$ from 2012 to 2014.

Are entities with a high to very high HDI level: (0.743-0.830)

High HDI level $=0.745$

High HDI level = 0.751

Very high HDI levels Nuevo León (0.790) and Querétaro (0.760)

Highest HDI level (0.830)
Average poverty

level $=35.6 \%$

Where: most of the entities decrease of maintained the same level of poverty. Whereas Coahuila and Morelos increased their poverty levels by $2.3 \%$ and Morelos by $6.8 \%$, respectively, from 2012 to 2014.

Poverty level $=49.6 \%$ Increased its poverty level by $4.6 \%$ with regard to 2012.

Poverty level $=35.4 \%$ Decreased by $4.4 \%$ with regard to 2012.

Average poverty level $=27.3 \%$

Both entities reduced their poverty level by an average of $2.75 \%$ with regard to

2012.

Poverty level $=28.4 \%$

Reduced its poverty level by $0.5 \%$ with regard to 2012 .
Found among the competitive entities that are below the national average, with Chiapas, Oaxaca, and Guerrero being the least competitive in the nation.

Found among the competitive entities that are below the national average, with Guanajuato, Sinaloa, and Yucatán being the most competitive of this conglomerate (above the national average).

Found among the competitive entities that are above the national average, with Chihuahua, Tamaulipas, and Morelos as the least competitive of this conglomerate.

Occupies 16th place, just below the national average.

Occupies 9th place in competitiveness.

Found among the most competitive entities with 4 th and 5th place, respectively.

The most competitive entity of Mexico. 
Table 8

ANOVA 2 factor test. Year 2006.

\begin{tabular}{|c|c|c|c|c|c|c|}
\hline & & Sum of squares & df & Quadratic mean & $F$ & Sig. \\
\hline \multirow{3}{*}{$\begin{array}{l}\text { REGR factor score } 1 \text { for } \\
\text { analysis } 1\end{array}$} & Inter-groups & 29.547 & 6 & 4.924 & \multirow[t]{3}{*}{84.700} & \multirow[t]{3}{*}{.000} \\
\hline & Intra-groups & 1.453 & 25 & .058 & & \\
\hline & Total & 31.000 & 31 & & & \\
\hline \multirow{3}{*}{$\begin{array}{l}\text { REGR factor score } 2 \text { for } \\
\text { analysis } 1\end{array}$} & Inter-groups & 28.086 & 6 & 4.681 & \multirow[t]{3}{*}{40.153} & \multirow[t]{3}{*}{.000} \\
\hline & Intra-groups & 2.914 & 25 & .117 & & \\
\hline & Total & 31.000 & 31 & & & \\
\hline
\end{tabular}

Source: Own elaboration (SPSS 21).

period of study it not only advanced in terms of technological capability, but also, according to PNUD (2015), it presented a relatively favorable ${ }^{9}$ mobility as it went from a 'high' to a 'very high' human development, implying that the people of Querétaro experience positive changes with regard to the rubrics of education, health, and income. Being the only state that, during this same period, managed said progress. In parallel, according to CONEVAL (2015), it has managed to reduce multidimensional poverty by $2.7 \%$ (from 2012 to 2014) and remains within the top 5 positions in terms of competitiveness (IMCO, 2014). For its part, according to estimates by PNUD (2015), Campeche shall be the first state to reach the HDI level of Mexico City (in 20 years) ${ }^{10}$ and in terms of competitiveness it moved forward 2 positions (now found in 13th place, above the national average), whereas in terms of multidimensional poverty, it managed to reduce it by $1.1 \%$. The state of Morelos draws attention due to the alarming increase in its levels of poverty, increasing by $6.8 \%$ (from 2012 to 2014). Furthermore, it moves down from the 20th position to the 21 st with regard to competitiveness (falling below the national average). In this case, it would be worthwhile for future studies to question the hypothesis in which, according to Tedesco (2010), the societies that are more intensively using the information and knowledge in their productive activities are significantly increasing social inequality; where social polarization is the result of an institutional system that does not take responsibility for the future of the people.

\section{Econometric validation test of the cluster analysis for the year 2006}

In the same vein, an ANOVA test has been carried out (see Table 8) to verify that the cluster analysis carried out for the year 2006 is adequate and whether there are significant differences between the obtained groups. The ANOVA and the post hoc tests allow us to verify that the cluster analysis carried out for the different variables is correct, in the sense of being able to prove the existence of significant differences between the seven groups in consideration. The results shown below confirm the merit of the analysis.

Within the ANOVA test (year 2006), given that $P=0.05>\mathrm{Sig}=0.000$ the $\mathrm{H}_{0}$ is rejected, there is a statistically significant difference between the total of the groups.

Once it has been determined that there are differences between the medians, the post hoc range test allows determining which medians differ. The post hoc range test identifies homogeneous subsets of medians that do not differ between them. Therefore, to prove if there are differences between

\footnotetext{
${ }^{9}$ Mobility evaluation from year 2006 to 2012 (PNUD, 2015).

${ }^{10}$ Under the assumption of the invariability of the growth trends.
} 
Table 9

Post hoc tests for factor 1-2. Year 2006.

\begin{tabular}{|c|c|c|c|c|c|c|c|c|c|c|}
\hline \multirow[t]{2}{*}{ Factor 1 (year 2006) ${ }^{1}$} & \multirow{2}{*}{$\begin{array}{l}\text { Average linkage } \\
\text { (between } \\
\text { groups) }\end{array}$} & \multirow[t]{2}{*}{$N$} & \multicolumn{2}{|c|}{ Subset } & \multirow[t]{2}{*}{ Factor $2\left(\right.$ year 2006) ${ }^{2}$} & \multirow{2}{*}{$\begin{array}{l}\text { Average linkage } \\
\text { (between } \\
\text { groups) }\end{array}$} & \multirow[t]{2}{*}{$N$} & \multicolumn{3}{|c|}{ Subset } \\
\hline & & & 1 & 2 & & & & 1 & 2 & 3 \\
\hline Student-Newman- & Cluster 5 & 9 & -0.4306927 & & Student-Newman- & Cluster 7 & 5 & -1.6247981 & & \\
\hline \multirow{3}{*}{ Keuls ${ }^{\mathrm{a}, \mathrm{b}}$} & Cluster 6 & 14 & -0.3483875 & & Keuls, a & Cluster 6 & 14 & & -0.1291626 & \\
\hline & Cluster 7 & 5 & & 0.1364949 & & Cluster 5 & 9 & & & 0.9575606 \\
\hline & Sig. & & 0.505 & 1 & & Sig. & & 1 & 1 & 1 \\
\hline \multirow[t]{4}{*}{ HSD of Tukey ${ }^{a, b}$} & Cluster 5 & 9 & -0.4306927 & & HSD of Tukey ${ }^{\mathrm{a}, \mathrm{b}}$ & Cluster 7 & 5 & -1.6247981 & & \\
\hline & Cluster 6 & 14 & -0.3483875 & & & Cluster 6 & 14 & & -0.1291626 & \\
\hline & Cluster 7 & 5 & & 0.1364949 & & Cluster 5 & 9 & & & 0.9575606 \\
\hline & Sig. & & 0.779 & 1 & & Sig. & & 1 & 1 & 1 \\
\hline \multirow[t]{3}{*}{ Waller-Duncan ${ }^{\mathrm{a}, \mathrm{c}}$} & Cluster 5 & 9 & -0.4306927 & & Waller-Duncan ${ }^{\mathrm{a}, \mathrm{c}}$ & Cluster 7 & 5 & -1.6247981 & & \\
\hline & Cluster 6 & 14 & -0.3483875 & & & Cluster 6 & 14 & & -0.1291626 & \\
\hline & Cluster 7 & 5 & & 0.1364949 & & Cluster 5 & 9 & & & 0.9575606 \\
\hline
\end{tabular}

HSD, honestly-significant-difference.

Source: Own elaboration (SPSS 21).

${ }^{1}$ The means of the groups of homogeneous subsets are shown. Based on observed means. The error term is the quadratic mean (Error) $=.058$. a. Uses the sample size of the harmonic mean $=7.842$. b. Alfa $=.05$. c. Reason for seriousness of the error of type $1 /$ type $2=100$.

2 The means of the groups of homogeneous subsets are shown. Based on observed means. The error term is the quadratic mean (Error) $=.117$. a. Uses the sample size of the harmonic mean $=7.842$. b. Alfa $=.05$. c. Reason for seriousness of the error of type $1 /$ type $2=100$. 
Table 10

Two factor ANOVA test. Year 2012.

\begin{tabular}{llrrrrr}
\hline & & Sum of squares & df & Quadratic mean & F & Sig. \\
\hline REGR factor score 1 for & Inter-groups & 28.870 & 6 & 4.812 & 56.465 & .000 \\
analysis 5 (factor 1) & Intra-groups & 2.130 & 25 & .085 & & \\
& Total & 31.000 & 31 & & 46.287 & .000 \\
REGR factor score 2 for & Inter-groups & 28.440 & 6 & 4.740 & .102 & \\
analysis 5 (factor 2) & Intra-groups & 2.560 & 25 & 31 & & \\
& Total & 31.000 & & & \\
& &
\end{tabular}

Source: Own elaboration (SPSS 21).

all the groups, further tests have been carried out in addition to the Student-Newman-Keuls, Tukey and Waller-Duncan HSD tests. ${ }^{11}$ The test has been carried out with the 3 groups that have more than one state, thus eliminating the case of Mexico City, Mexico, Jalisco, and Nuevo León which present clear differences with the rest of the groups.

Table 9 presents the results of the post hoc tests for factor 1, defined as the absorption and innovation capability; it can be observed that:

- There is a statistically significant difference between group 5 and group 7 .

- There is a statistically significant difference between group 6 and group 7 .

- However, there are no significant differences between group 5 and group 6, due to Sig. >0.05, in this case $0.5>0.05$. In the dispersion diagram (Fig. 3), a certain coincidence can be observed.

Similarly, the results of the post hoc tests for factor 2, defined as the infrastructure technological capabilities, show that there is a statistically significant difference between all the conglomerates.

Econometric validation test of the cluster analysis for the year 2012

Similarly, the ANOVA test has been carried out to verify that the cluster analysis done for the year 2012 is adequate and if there are significant differences between the groups obtained. This can be observed in Table 10 .

The results of the ANOVA test reject the $\mathrm{H}_{0}$, therefore, there is a statistically significant difference between the total groups, given that $P=0.05>\operatorname{Sig}=0.000$.

Furthermore, the post hoc tests have been carried out with the 4 groups that have more than one state, thus eliminating the case of Mexico City, Mexico and Jalisco, which present clear differences with the rest of the groups.

Table 11 shows the results of the post hoc tests for factor 1, defined as the absorption and innovation capability, where it can be observed that:

\footnotetext{
11 The Student-Newman-Keuls ${ }^{\mathrm{a}, \mathrm{b}}$ Test is a multiple comparison test that allows comparing the medians of the $t$ levels of a factor after having rejected the $\mathrm{H} 0$ of median equality through the ANOVA technique. The Tukey ${ }^{\mathrm{a}, \mathrm{b}}$ HSD test utilizes the studentized range statistic to carry out all the comparisons by pairs between the groups and establishes the error rate per experiment as the error rate for the set of all the comparisons by pairs. The Waller-Duncan ${ }^{\mathrm{a}, \mathrm{c}}$ test utilizes the Bayesian approximation. This range test employs the harmonic median of the sample size when the sampled sizes are not equal (Martín, Cabero, \& de Paz, 2008).
} 
Table 11

Post hoc tests for factor 1.2. Year 2012.

\begin{tabular}{|c|c|c|c|c|c|c|c|c|c|c|}
\hline \multirow[t]{2}{*}{ Factor 1 (year 2012) } & \multirow{2}{*}{$\begin{array}{l}\text { Average linkage } \\
\text { (between } \\
\text { groups) }\end{array}$} & \multirow[t]{2}{*}{$N$} & \multicolumn{2}{|c|}{ Subset } & \multirow[t]{2}{*}{ Factor $2(\text { year } 2012)^{2}$} & \multirow{2}{*}{$\begin{array}{l}\text { Average linkage } \\
\text { (between } \\
\text { groups) }\end{array}$} & \multirow[t]{2}{*}{$N$} & \multicolumn{3}{|c|}{ Subset } \\
\hline & & & 1 & 2 & & & & 1 & 2 & 3 \\
\hline \multirow{6}{*}{$\begin{array}{l}\text { Student-Newman- } \\
\text { Keuls }^{\mathrm{a}, \mathrm{b}, \mathrm{c}}\end{array}$} & Cluster 5 & 11 & -0.4538141 & & \multirow{5}{*}{$\begin{array}{l}\text { Student-Newman- } \\
\text { Keuls }^{\text {a,b }}\end{array}$} & Cluster 7 & 5 & -1.5369134 & & \\
\hline & Cluster 6 & 11 & -0.3682284 & & & Cluster 6 & 11 & & -0.2790508 & \\
\hline & Cluster 7 & 5 & & 0.208895 & & Cluster 5 & 11 & & & 0.7911984 \\
\hline & Cluster 2 & 2 & & 0.3759092 & & Cluster 2 & 2 & & & 1.1697297 \\
\hline & Sig. & & 0.663 & 0.397 & & Sig. & & 1 & 1 & 0.087 \\
\hline & Cluster 5 & 11 & -0.4538141 & & \multirow{5}{*}{ HSD of Tukey ${ }^{a, b}$} & Cluster 7 & 5 & -1.5369134 & & \\
\hline \multirow{4}{*}{ HSD of Tukey ${ }^{a, b, c}$} & Cluster 6 & 11 & -0.3682284 & & & Cluster 6 & 11 & & -0.2790508 & \\
\hline & Cluster 7 & 5 & & 0.208895 & & Cluster 5 & 11 & & & 0.7911984 \\
\hline & Cluster 2 & 2 & & 0.3759092 & & Cluster 2 & 2 & & & 1.1697297 \\
\hline & Sig. & & 0.971 & 0.824 & & Sig. & & 1 & 1 & 0.305 \\
\hline \multirow{4}{*}{ Waller-Duncan ${ }^{\mathrm{a}, \mathrm{b}, \mathrm{d}}$} & Cluster 5 & 11 & -0.4538141 & & \multirow{4}{*}{ Waller-Duncan ${ }^{\mathrm{a}, \mathrm{c}}$} & Cluster 7 & 5 & -1.5369134 & & \\
\hline & Cluster 6 & 11 & -0.3682284 & & & Cluster 6 & 11 & & -0.2790508 & \\
\hline & Cluster 7 & 5 & & 0.208895 & & Cluster 5 & 11 & & & 0.7911984 \\
\hline & Cluster 2 & 2 & & 0.3759092 & & Cluster 2 & 2 & & & 1.1697297 \\
\hline
\end{tabular}

HSD, honestly-significant-difference.

Source: Own elaboration (SPSS 21).

1 The means of the groups of homogeneous subsets are shown. Based on observed means. The error term is the quadratic mean (Error) $=.085$. a. Uses the sample size of the harmonic mean $=4.536$. b. The sizes of the groups are different. The harmonic mean of the group sizes will be used. Type I error levels are not guaranteed. $\mathrm{c}$. Alfa $=.05$. $\mathrm{d}$. Reason for seriousness of the error of type 1/type $2=100$.

${ }^{2}$ The means of the groups of homogeneous subsets are shown. Based on observed means. The error term is the quadratic mean (Error) $=.102$. a. Uses the sample size of the harmonic mean $=4.536$. b. Alfa $=.05$. c. Reason for seriousness of the error of type $1 /$ type $2=100$. 
- There is a statistically significant difference between group 5 and group 7 .

- There is a statistically significant difference between group 5 and group 2 .

- There is a statistically significant difference between group 6 and group 7 .

- There is a statistically significant difference between group 6 and group 2 .

- However, there we no significant differences between group 5 and group 6, due to Sig. $>0.05$, in this case $0.66>0.05$. In the dispersion diagram (Fig. 3), certain coincidence can be observed. This is the same case between group 7 and group 2 .

Furthermore, the results of the post hoc tests for factor 2 are also visualized, defined as the infrastructure technological capabilities, indicating that there is a statistically significant difference between all the conglomerates, except for conglomerates 5 and 2, due to Sig. $>0.05$, in this case $0.08>0.05$.

Finally, it could be said that the post hoc tests have shown significant differences in most of the cases between the groups in consideration, and at the set level (as proven in the results of the ANOVA and the dispersion graph) there are significant differences between the 7 conglomerates, therefore, the cluster analysis carried out for both periods is acceptable.

\section{Conclusions}

This work shows the results of an empirical research on the differences between the entities of the Mexican republic with regard to their technological capability and their evolution in a six-year period (2006-2012). The results show the existence of seven groups of states, clearly characterized by different levels of technological capability. The predominance of conglomerates 5, 6, and 7 can be observed in Figure 4. This lets us see that groups 1-4 manifest satisfactory results in some

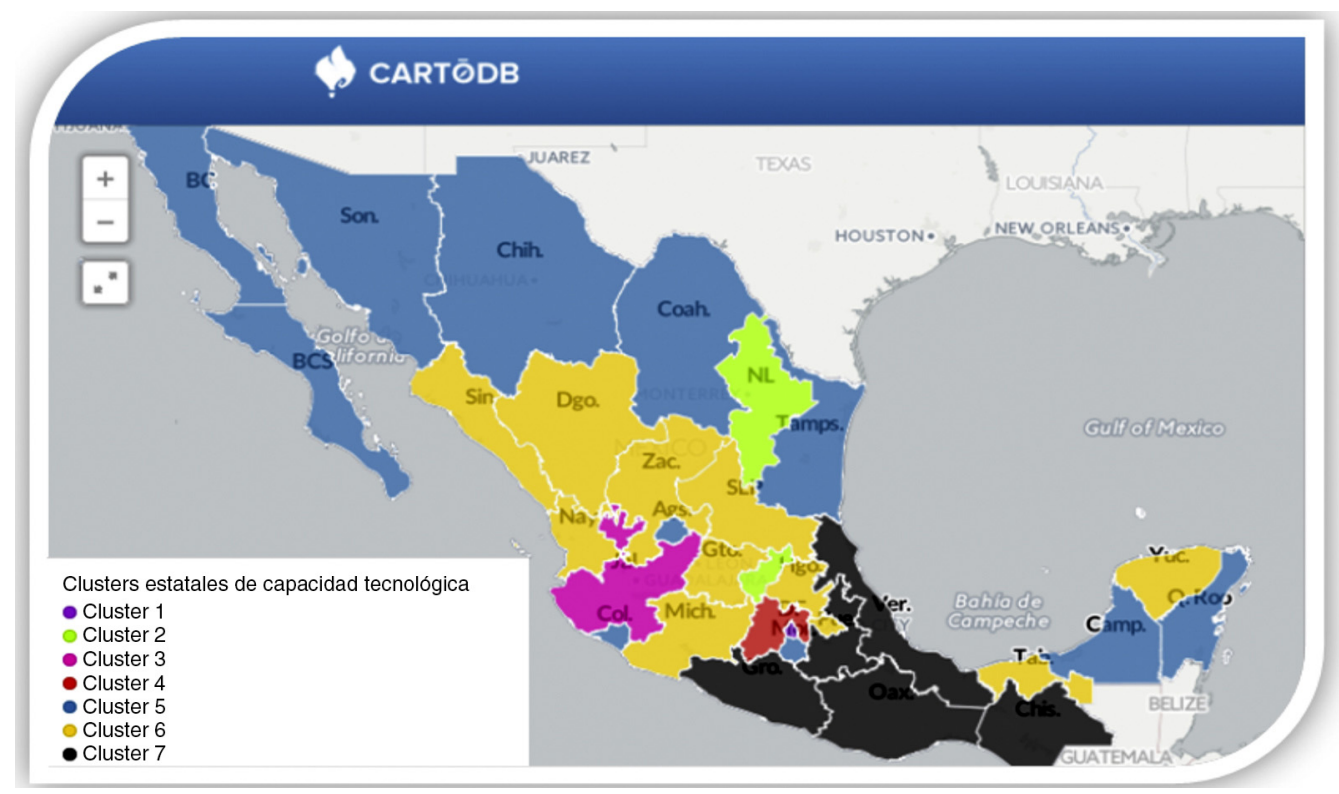

Fig. 4. Mapping of the state conglomerates of technological capability in Mexico 2012.

Source: Own elaboration with CARTO DB, also found at: http://cdb.io/1tJkRKm. 
of the factors analyzed (absorption and innovation capability and/or infrastructure technological capability); however, said groups are the least numerous (5 entities). The need to decentralize the scientific and technological capabilities is clear, to contribute to the promotion of economic development and the well-being of all the regions in the country, taking into consideration their productive vocation.

The classification of the entities into seven different conglomerates and the analysis of their evolution through 6 years allows us to conclude that, in general, the gap in technological capability and consequently in technological innovation between the states of the Mexican Republic is broad, and is concentrated in a few entities (Federal District, Nuevo León, Querétaro, Jalisco, State of Mexico). From 2006 to 2012, only 3 entities (Querétaro, Morelos, and Campeche) managed to move to a more advanced conglomerate. The situation of Querétaro stands out, given that in 2006 it was in conglomerate 6 , and in 2012 it had moved to the second conglomerate, accompanying Nuevo León only below Mexico City.

This speaks of the fact that, despite that technological capability and thereby innovation is a gradual and accumulative process, there is a possibility that in a period of 6 years the states can make considerable progress in terms of their technological capability. The example has been set by these three states, both with regard to their absorption and innovation capability as well as their infrastructure technological capability. On the other hand, some implications can be pointed out: the first refers to the unequal distribution of the technological capability between the conglomerates observed. The combination of the two factors of the technological capability (absorption and innovation capability and infrastructure technological capability) performs an important role when it comes to positioning each state innovation system. Each state ought to not only observe and try to imitate those that are in a more advanced position or conglomerate, but should also draw their own itinerary departing from their existing technological capability, trying to succeed in the improvement of their position (García et al., 2012).

The second implication refers to the general evolution of the innovation systems. In this sense, it ought to be analyzed how many states have improved and moved toward a superior conglomerate and how many have regressed. As can be observed, no state has regressed to an inferior group, rather some states have moved to a superior one. Specifically, two states moved from conglomerate 6 to 5 (Morelos and Campeche), one state moved from conglomerate 6 to 2 (Querétaro), and 29 states remained with practically no change. In general, the variations in their positions during the six years considered have not been too significant, which could be due to the fact that technological capabilities are slowly generated and destroyed with the course of time, even in periods of rapid economic growth (Archibugi \& Castellacci, 2008).

It is also worth mentioning that the distances between conglomerate 6 and 5 have been reduced in terms of infrastructure technological capability; the same occurs between conglomerate 5 and 2. However, in the positive quadrants in general, only 4 conglomerates ( 5 states) are found clearly positioned, which appears to coincide with the global dynamic of worldwide technology, in which few entities generate most of the knowledge (Archibugi \& Pianta, 1996). In the long term, the aforementioned suggests that Mexico is evolving toward a region in which a small group of states, around $16 \%$, dominate the technological landscape, whereas the remaining $84 \%$ of the states would be further delayed.

Below we present the main conclusions in greater detail, in terms of possible action areas for each of the groups identified in the empirical analysis.

Regarding the states situated in conglomerates 6 and 7, these are the ones found in the worst positions in terms of technological capability (absorption and innovation) and, therefore, have the need for clear action to drive innovation forward. In order to reduce their technological difference, 
they could increase their investment in $R \& D$ as a greater public and private investment capacity in R\&D could help the industry develop their research interests, which in conjunction with specific initiatives intended to increase entrepreneurial culture and innovation in the SMEs could also promote innovation (García et al., 2012).

In conglomerate 7, Puebla and Veracruz could increase their efforts, mainly in terms of infrastructure technological capability. The states integrated in groups 6 and 7 need to make an additional effort to improve the technological infrastructures, given that they have a rather low absorption capability. Regarding group 5, it finds itself in a positive position in terms of infrastructure technological capabilities, however, their efforts ought to be guided toward increasing their absorption and innovation capability. Conglomerates 3 and 4 maintain a competitive position in terms of their absorption and innovation capability, nevertheless, they manifest certain deficiencies in terms of their infrastructure technological capability and thus should be reinforced first and foremost. Conglomerate 2, comprised of Nuevo León and Querétaro, is the best positioned in terms of infrastructure technological capability and regarding its absorption and innovation capability it is within the positive quadrant. The companies of the states that comprise it determine the technological competitiveness of the region. These states must pay particular attention to developing strategies that favor the creation and distribution of knowledge. To this end, they could improve the quality of the research institutions, strengthen the collaboration between universities and companies, and improve the laws related to information and communication technologies, thus facilitating the interaction between all the agents of the innovation system and providing collaboration with other foreign actors that would help them create new knowledge (Clarysse and Muldur, 2001) cited by (García et al., 2012). In any case, there is still a long way to go to converge with conglomerate 1 in terms of the analyzed components.

Finally, regarding conglomerate 1 , this is the most advanced in absorption and innovation capability, and is comprised of only Mexico City. In this sense, the well positioned states must try to gain new talent, thus facilitating the creation and distribution of first level knowledge (Archibugi \& Coco, 2004). This group could represent a point of reference for some less advanced groups with the purpose of identifying actions guided toward improving innovation which could help advance to a superior conglomerate.

The main contributions of this work are the following:

From the point of view of the literature on technological capabilities, these results contribute with new empirical evidence on the existence of seven different groups of states in the Mexican Republic in terms of their technological capability, indicating the dimensions in which each group differs from the rest. Furthermore, it is clearly shown that the differences between states are well reflected by the two factors, as indicated by the results of the factor analysis and the cluster analysis. This research and classification could help identify and understand the challenges and opportunities that the states of each conglomerate face in the future.

Despite the contributions of this empirical study, it is necessary to note its limitations. There is no doubt that the literature on technological change needs to continue to progress in order to find better measurement tools. In this sense, the indicators contemplated in this work could be reinforced using triangulation methods, such as the use of synthetic indexes, or combining them with other indicators elaborated by different organizations or institutions, as is advisable by García-Ochoa Mayor, Blázquez de la Hera, and López Sánchez (2012). Furthermore, it is critical to prepare stratified statistical data at a state level, due to the fact that the perception is that the current situation of the statistics generation subsystem on Science and Technology in Mexico is limited, and indicates areas of opportunity for its improvement.

Table 12 shows the main advantages and limitations of the study: 
Table 12

Advantages and limitations of the present research in comparison with previous studies.

\begin{tabular}{|c|c|}
\hline Advantages & Limitations \\
\hline $\begin{array}{l}\text { Properly establishes for the first time a specific study } \\
\text { focused on the technological capability in Mexico, } \\
\text { separated by states, taking the taxonomy of Cepal } \\
\text { (2007) as base. }\end{array}$ & $\begin{array}{l}\text { Given the methodology and the statistical techniques } \\
\text { used, a positioning ranking is not generated. }\end{array}$ \\
\hline $\begin{array}{l}\text { Takes advantage of public data (OPEN) which, in } \\
\text { comparison with the studies of the FCCyT (2014), a } \\
\text { large quantity of it is provided by different } \\
\text { institutions as: "confidential information". }\end{array}$ & $\begin{array}{l}\text { According to the taxonomy of Cepal (2007) with } 3 \\
\text { dimensions of study: only } 16 \text { variables are utilized, } \\
\text { leaving out the issue of gender equity and other variables } \\
\text { that are visualized in the study of the FCCyT (2014). }\end{array}$ \\
\hline \multicolumn{2}{|l|}{$\begin{array}{l}\text { Graphically identifies the distances between } \\
\text { conglomerates, evidencing the regional gaps in terms } \\
\text { of technological capability. }\end{array}$} \\
\hline \multicolumn{2}{|l|}{$\begin{array}{l}\text { The evolution of the technological capability } \\
\text { experienced in a six-year period (2006-2012) is } \\
\text { identified. }\end{array}$} \\
\hline \multicolumn{2}{|l|}{$\begin{array}{l}\text { The methodology utilized in this research allows } \\
\text { obtaining a division with a solid } \\
\text { theoretical-methodological support that contributes to } \\
\text { defining a better classification of regional spaces in } \\
\text { terms of technology. Different form the study of El } \\
\text { Índice de Economía del Conocimiento/Fundación } \\
\text { Este País (2005 and 2007), that given its division " } a \\
\text { priori", favors its purely geographical fragmentation, } \\
\text { instead. }\end{array}$} \\
\hline $\begin{array}{l}\text { It can be systematically replicated to evaluate the } \\
\text { progress and regression with certain periodicity. }\end{array}$ & \\
\hline
\end{tabular}

Source: Own elaboration.

Finally, it is worth highlighting the need to carry out in-depth studies of each state to be able to propose differentiated technological policies, given that what this work intended was to note possible action areas in each state, according to the positioning obtained and the evolution observed in each of them. The identification of the weak areas of each entity regarding technological capability suggests possible roads or routes for their improvement, which must obviously be supplemented with in-depth studies in each case.

\section{Reflections}

This work is an effort to impact on the particular analysis of the CTI, but from a perspective that allows properly identifying the technological capabilities at a state level, grouping together the states that share similar conditions in said matter. The main objective is to have a map that draws the distances and the road to follow, from one conglomerate to another, in the interest of progress and competitiveness. And the second objective for these types of studies is to be a source of reference to incur in differentiated technological policies and in accordance with the relative needs of each group of states. According to Dominguez and Brown (2004), it is necessary to draft a technological policy in Mexico to support the accumulation of said technological capabilities.

Therefore, it is quite pertinent to open the discussion regarding the programs and instruments whose purpose incurs not only in the increase of the technological capabilities of the states, but 
also in the decrease of regional asymmetries and the promotion of the linkage between marginal and developed areas (social and technologically).

Let us begin with the National Development Plan (2013-2018), whose objectives are to integrate and overcome the regional imbalances. From the aforementioned, the PECITI (2014) seeks to determine strategies for regional development, for which it has two instruments that seek to promote development in the states and strengthen their scientific and technological capabilities. Said instruments are the FOMIX (Mixed Fund) and the FORDECyT (Fondo Institucional de Fomento Regional para el Desarrollo Científico, Tecnológico y de Innovación), the latter is a fund of relatively 'recent creation' given that it was built from the Expenditure Budget of the Federation of 2009 in the interest of creating an instrument that would address, from a broader perspective, the integration and collaboration between states to contribute in overcoming the regional imbalances and asymmetries; which are proven and stressed in this study.

Currently, FOMIX and FORDECyT supplement each other to drive the decentralization policy and to promote regional development based on knowledge (FCCyT, 2012). However, from our perspective, FORDECyT needs better monitoring, as in its short 6 years of existence there is still much to be learned and improved. Despite how it has been indicated by the FCCyT (2012), this fund reveals its high potential in financed projects that address development problems, needs, and opportunities to promote regions based on science, technology, and innovation. Said anchoring has clearly been unstable, with notable ups and downs since its creation, given that according to statistics of the CONACyT (2015), the Regional Fund presented a 67\% decrease from 2009 to 2012. However, from 2012 to date, it manifests an increase of $440 \%$. Although the increase is overly plausible, these ups and downs are without a doubt what alter the regional technological dynamic that interrupts the accumulation and consolidation of the technological capabilities necessary to innovate. It has gotten to the point that it is necessary to endorse the fundamental belief that "the cutbacks in science are short-sighted, because they are cutbacks on future perspectives" (Heuer, 2015).

Thus, speaking of regional funds, it is necessary to consider the distribution and transparency of the FONREGION, ${ }^{12}$ whose purpose is to have less socially asymmetric states. This fund, according to PNUD (2015), shows that its projects were not aligned with the regional needs (mainly in Guerrero, Oaxaca, and Chiapas), nor with the objectives of the country to reduce poverty and inequality; given that the resources were not directed to the regions or groups that needed them most, and therefore, the transparency of the use of said resources is questionable.

In parallel to these efforts, the INAES (National Institute of Social Economy) has also recently participated in the actions derived from the Innovative Development Program 2013-2018, which has the great challenge of being able to converge social innovation and technological innovation. The social economy and the economy of knowledge begin to be interlinked and their monitoring and transparency become necessary to corroborate the correct linking of the social needs with the existing and potential technological capabilities. This as a means to ensure the state and regional competitiveness; and, in this manner, according to Oppenheimer (2014), making it possible for technology to reach those most in need, thus connecting science with the fight against poverty. In this manner, it is possible to achieve the longed for change in which Mexican innovation incentivizes the innovation that looks after the poor (Muñoz, 2014).

\footnotetext{
${ }^{12}$ FONREGION seeks to drive human development in the states with greater setbacks and, consequently, strengthening the social mobility for egalitarian opportunities.
} 
According to FCCyT (2012, p. 17), "progress has been made towards decentralization, according to which the innovation processes must emerge locally, in this case, from the states and regions, trying to promote what is known as innovative territories, which are understood as spaces or regions that take advantage of their conventional and non-conventional resources (the existing capabilities and those that are yet to be developed)".

In this sense, for Oppenheimer (2014), the places where innovation flourishes (innovative territories) generally glorify talent more than money. Thus, it is worth remembering that the virtuous circle of innovation consists in converting money (investment in CTI) into knowledge and at separate time, turning knowledge into money (new, commercially accepted goods). This inevitably requires differentiated technological policies that incentivize the technological capabilities of the regions. In Mexico, one of the biggest challenges is promoting region development without generating greater regional imbalances, and achieving a culture of innovation accompanied by strategies that persuade the concentration of creative-innovating minds to the most disadvantaged states.

Therefore, saying that Mexico does not grow is forgetting that in our country there are states that during certain periods could very well be classified as Asian tigers, co-inhabiting with entities that suffer economic crises of similar proportions to Greece and, therefore, the problem is not that Mexico does not grow, but rather that it grows at 32 different paces (Ríos, 2014).

The results of this research suggest a similar analogy, Mexico does make effective use of the technological knowledge to change existing technologies and develop new products and processes, but said capability progresses at 7 different paces ( 7 state conglomerates of technological capability). Therefore, it is not coincidental that the states with lower levels of technological capability manifest, on the one hand, a lower competitiveness and social performance, accompanied by greater poverty and social setback.

Therefore, in order to increase said capabilities a benchmarking exercise is necessary, taking as point of reference those states that are doing a good job in terms of promoting innovation by granting the necessary conditions to execute it. Focusing on Mexico City, Nuevo León, and Querétaro $^{13}$ as success cases, may perhaps be more beneficial than looking toward Switzerland, the United Kingdom or Sweden, ${ }^{14}$ given that the former are part of our context. However, for the observance of the former, different research types and methodologies are required to analyze the subject matter.

The findings of this investigation enhance the debate and discussion regarding the technological innovation capabilities in Mexico. Some of the results are convergent with previous studies, for example, the top 3 states with greater innovation capabilities and infrastructure technological capabilities coincide with the top 3 presented in the National Ranking of Science, Technology, and Innovation (FCCyT, 2014). However, given that the research methodology and focus is different, it can be appreciated that the stratification of these 7 conglomerates set the norm to reflect how, generally, innovation tends to be stratified in three groups. ${ }^{15}$ Nevertheless, the results of this investigation suggest the existence of 4 groups of states (almost isolated) that show a clearly different and efficient dynamic in terms of technological capability when compared to the rest of the republic.

\footnotetext{
${ }^{13}$ In our study, Mexico City came out as the leading state in technological capabilities, whereas Nuevo Léon and Querétaro belong to the second conglomerate.

14 Better Ranking countries according to (WIPO, 2014).

15 Clusters A, B, C in the National Ranking of Science, Technology, and Innovation (FCCyT, 2014). States in construction, states in transition, and states in consolidation according to PECITI, 2014-2018.
} 
The situation of Chiapas, Guerrero, and Oaxaca is worrying. For their part, conglomerates 5 and 6 are also located in the negative quadrants, the states that congregate in said groups are considered states in transition in terms of CTI investment and economy of knowledge (PECITI, 2014). Finally, conglomerates 1 to 4 present better conditions with regard to their technological capabilities, in this case, the consolidating states are only: Mexico City, Nuevo León, Querétaro, and Jalisco. Derived from this, the following questions emerge: why the technological capability seems to concentrate in just a few states? In what measure does this depend on location? How does each conglomerate relate with economic development? And how does the creation and accumulation of state technological capabilities impact both in the standard of living and quality of life of the Mexican people? Questions that double as research suggestions and which could be answered under diverse methodologies. Finally, good expectations are anticipated, given that according to PECITI (2014), it has been proposed that the GIDE/GDP for 2018 shall be of $1 \%$, a figure that would drive the capabilities of Science, Technology, and Innovation. However, a pending task is to reverse the fact that magical thinking is currently privileged over logical-scientific thinking, since according to the Survey on Public Perception of Science and Technology in Mexico (Enpecyt, 2011), 57.5\% of Mexicans consider that due to their knowledge, "researchers and scientists have a power that makes them dangerous". For the incentives regarding Science and Technology to work, said perception must change, and this should be reflected on the increase of our human resources dedicated to research, science, and technology.

\section{References}

Acemoglu, D., \& Robinson, J. (2013). Por qué fracasan los países. México: CRÍTICA.

Álvarez, R. (1995). Estadística multivalente y no paramétrica con SPSS. Madrid: Díaz de Santos.

Archibugi, D. (1988). In search of a useful measure of technological innovation (to make economists happy without discontenting technologists). Technological Forecasting and Social Change, 34, 253-277.

Archibugi, D., \& Castellacci, F. (2008). The technology clubs: The distribution of knowledge across nations. Research Policy, 37, 1659-1673. http://dx.doi.org/10.1016/j.respol.2008.08.006

Archibugi, D., \& Coco, A. (2004). A new indicator of technological capabilities for developed and developing countries (ArCo). World Development, 32, 629-654. http://dx.doi.org/10.1016/j.worlddev.2003.10.008

Archibugi, D., \& Coco, A. (2005). Measuring technological capabilities at the country level: A survey and a menu for choice. Research Policy, 34, 175-194. http://dx.doi.org/10.1016/j.respol.2004.12.002

Archibugi, D., \& Pianta, M. (1996). Measuring technological change through patents and innovation surveys. Technovation, 16, 451-468. http://dx.doi.org/10.1016/0166-4972(96)00031-4

Biggs, T., Shah, M., \& Srivastava, P. (1995). Technological capabilities and learning in African enterprises. World Bank technical paper; no. WTP 288. Africa Technical Department series. Washington, D.C.: The World Bank [accessed 5 Oct 2016]. Available in: http://documents.worldbank.org/curated/en/649901468773714947/Technological-capabilitiesand-learning-in-African-enterprises

Blázquez de le Hera, M. L., \& García-Ochoa Mayor, M. (2009). . pp. 16-33. Clusters de innovación tecnológica en Latinoamérica (Vol. 3) GCG Georgetown University - Universia.

Borrastero, C. (2012). Notas sobre la cuestión del excedente en las teorías evolucionistas neoschumpeterianas. Papeles de trabajo. pp. 100-126. Revista electrónica del Instituto de Altos Estudios Sociales de la Universidad Nacional de General San Martín.

Brunner, J. (2011). Chile: informe sobre capacidades tecnológicas. pp. 1-41. Instituto de Economía Política.

Buesa, M., Martínez, M., Heijs, J., \& Baumert, T. (2002). Los sistemas regionales de innovación en España: Una tipología basada en indicadores económicos e institucionales. Economía Industrial, 347, 15-32.

Calderón, M., \& Hartmann, D. (2010). Una revisión del pensamiento evolucionista y el enfoque de los sistemas de innovación. RUDICS, 1-18.

Cepal. (2007). Serie Estudios y Perspectivas. Indicadores de capacidades tecnológicas en América Latina. México: Naciones Unidas. Available from: http://www.cepal.org/es/publicaciones/5014-indicadores-de-capacidades -tecnologicas-en-america-latina (accessed 10.01.17) 
Chinaprayoon, C. (2007). Science, technology and innovation composite indicators for developing countries. Georgia Institute of Tecnology.

Close, E., \& Garita, M. (2011). La innovación en las empresas de Guatemala. ECO Revista Académica, 27-36.

CONACyT (2015). Estadísticas FORDECYT. Disponible en: http://www.conacyt.mx/index.php/fondo-institucional-defomento-regional-para-eldesarrollo-cientifico-tecnologico-y-de-innovacion-fordecyt

CONEVAL (2015). Medición de la pobreza en México y en las entidades federativas 2014. Disponible en: http://www.coneval.gob.mx/Medicion/Documents/Pobreza\%202014_CONEVAL_web.pdf

Diaconu, M. (2011). Technological innovation: Concept, process, typology and implications in the economy. Theoretical \& Applied Economics, 18(10), 127-144.

Dominguez, L., \& Brown, F. (2004). Medición de las capacidades tecnológicas en la industria mexicana. Revista de la CEPAL, 83, 135-161.

Dosi, G. (2008). La interpretación evolucionista de las dinámicas soio económicas. In R. Viale (Ed.), Las nuevas economías. De la economía evolucionista a la economía cognitiva: Más allá de las fallas de la teoría neoclásica (pp. 29-44). México: Flacso México.

Dutréit, G., \& Sutz, J. (2014). Sistemas de innovación para un desarrollo inclusivo. México: FCCyT.

Dutrénit, G., Capdeville, M., Corona, J., Puchet, M., \& Veracruz, F. (2010). El Sistema Nacional de Innovación Mexicano. pp. 1-62. UAM.

Enpecyt. (2011). Encuesta sobre la Percepción Pública de la Ciencia y la Tecnología en México. INEGI.

FCCyT. (2012). Integración regional para el surgimiento de territorios innovadores. México: CONACyT, Foro Consultivo Científico y Tecnológico.

FCCyT. (2014). Ranking Nacional de Ciencia Tecnología e Innovación. Capacidades y Oportunidades de los sistemas estatales de CTI. México: FCCyT.

García, M., Blázquez, M., \& Ruiz, E. (2012). Empirical study of national technological innovation capability in Africa. SAJEMS, 440-463.

García-Ochoa Mayor, M., Blázquez de la Hera, M. L., \& López Sánchez, J. I. (2012). Uso y aplicación de la técnica de análisis estadístico multivariante de cluster sobre la capacidad de innovación tecnológica en Latinoamérica y España. Innovar, 22, 21-40.

Guzmán, D. (2008). Las capacidades tecnológicas en la industria del calzado en México. México: I.P.N.

Heuer, R. (2015). Modelo europeo no es viable sin inversión en ciencia. México: El Universal [accessed 5 Oct 2016]. Available in: http://www.eluniversal.com.mx/articulo/ciencia-y-salud/ciencia/2015/07/29/modeloeuropeo-no-es-viable-sin-inversion-en-ciencia

IMCO (2014). Índice de Competitividad Estatal 2014. Disponible en: http://imco.org.mx/indices/documentos/ 2014_ICE_Libro_Las_reformas_y_los_estados.pdf

Lall, S. (1992). Technological capabilities and industrialization. World Development, 20(2), 165-186.

Martín, Q., Cabero, M., \& de Paz, Y. (2008). Tratamiento estadístico de datos con SPSS. España: Thomson.

Morales, M. (2009). Teoría Económica Evolutiva de la Empresa: ¿una alternativa a la teoría neoclásica? Revista Latinoamericana de Economía, 161-183.

Muñoz, R. (2014). Innovación a la mexicana. México: conecta.

Oppenheimer. (2014). Crear o morir: la esperanza de América latina y las 5 claves de la innovación. México: DEBATE.

Ortega, R. (2005). Aprendizaje y acumulación de capacidades tecnológicas en un grupo del sector siderúrgico. INNOVAR, Revista de Ciencias Administrativas y Sociales, 90102.

PECITI. (2014). Programa Especial de Ciencia, Tecnología e Innovación 2014-2018. CONACyT.

Pedroza, H. (2006). Sistema de análisis estadístico con SPSS. Nicaragua: INTA.

Pérez, C., \& Lara, G. (2015). Tecnología y desarrollo. En Lara, G., Conectando la capacidad tecnológica con indicadores de desarrollo: un análisis estadístico en México. Fontarama. ISBN: 978-607-736-215-9.

Programa de las Naciones Unidas para el Desarrollo (PNUD) (2015). Movilidad social [accessed 5 Oct 2016]. Available in: http://www.mx.undp.org/content/dam/mexico/docs/Publicaciones/PublicacionesReduccionPobreza/fsvidadigna/ PNUD_MovilidadSocial.pdf?download

Quiñones, A., \& Tezanos, S. (2011). Cooperación científico-tecnológica para el desarrollo internacional: una apuesta desde la innovación. Available from: http://www.ciberoamericana.com/pdf/DT_2011_02.pdf (accessed 10.01.17)

Ríos, V. (2014). México sí crece, solo que a 32 pasos diferentes. Excelsior.

Rózga, R. (2003). Sistemas regionales de innovación: antecedentes, origen y perspectivas. Convergencia. Revista de Ciencias Sociales, 225-248.

Schumpeter, J. (2005). Development. Journal of Economic Literature, 108-120.

Stern, S., Porter, M. E., \& Furman, J. L. (2000). The Determinants of National Innovative Capability. NBER Working Paper Series. http://dx.doi.org/10.3386/w7876 
Tedesco, J. (2010). Educar en la sociedad del conocimiento. México: Fondo de Cultura Económica.

Torres, A. (2006). Aprendizaje y construcción de capacidades tecnológicas. Journal of Technology Management \& Innovation, 12-24.

Ulku, H. (2004). R\&D, innovation, and economic growth: An empirical analysis. IMF Working Paper, 4-28.

Velarde, E., Garza, E., \& Coronado, E. (2011). El desarrollo de capacidades tecnológicas y la vinculación con instituciones educativas. Global Conference on Business and Finance Proceedings, 6(2), 1-7.

WIPO. (2014). The Global Innovation Index 2014. INSEAD. Available from: https://www.globalinnovationindex. org/userfiles/file/reportpdf/gii-2014-v5.pdf (accessed 10.01.17) 